\title{
The respiratory energy requirements involved in nocturnal carbohydrate export from starch-storing mature source leaves and their contribution to leaf dark respiration
}

\author{
T.J. Bouma ${ }^{1,2,4}$, R. De Visser ${ }^{2}$, P.H. Van Leeuwen ${ }^{2}$, M.J. De Kock ${ }^{2}$ and H. Lambers ${ }^{3}$ \\ 'Department of Theoretical Production Ecology, Wageningen Agricultural University, PO Box 430, \\ NL-6700 AK Wageningen, The Netherlands \\ ${ }^{2} D L O-R e s e a r c h$ Institute for Agrobiology and Soil Fertility (AB-DLO), PO Box 14, NL-6700 AA Wageningen, \\ The Netherlands \\ ${ }^{3}$ Department of Plant Ecology and Evolutionary Biology, Utrecht University, Sorbonnelaan 16, \\ NL-3584 CA Utrecht, The Netherlands
}

Received 9 May 1994; Accepted 12 May 1995

\begin{abstract}
The present study explores the potential contribution of the energy requirements associated with nocturnal carbohydrate export to (1) the fraction of dark respiration correlating with leaf nitrogen concentration and (2) the dark respiration of mature source leaves. To this end, we determined the nocturnal carbohydrate-export rates from leaves with an optimal nitrogen supply, and the correlation between the nitrogen concentration and the dark respiration of leaves. The specific energy costs of carbohydrate export from starch-storing source leaves were determined both experimentally and theoretically. The present estimate of the specific energy cost involved in carbohydrate export as obtained by linear regression $\left(0.70 \mathrm{~mol} \mathrm{CO}_{2}\right.$ [mol sucrose] $\left.{ }^{-1}\right)$, agrees well with both literature data obtained by different methods $\left(0.47\right.$ to $1.26 \mathrm{~mol} \mathrm{CO}_{2}$ [mol sucrose] $\left.^{-1}\right)$ and the theoretically calculated range for starch-storing species ( 0.40 to $1.20 \mathrm{~mol} \mathrm{CO}_{2}$ [mol sucrose] $\left.{ }^{-1}\right)$. The conversion of starch in the chloroplast to sucrose in the cytosol is a major energy-requiring process. Maximally 42 to ' 107 ' $\%$ of the slope of the relationship between respiration rate and organic nitrogen concentration of primary bean leaves, may be ascribed to the energy costs associated with nocturnal export of carbohydrates. Total energy costs associated with export were derived from the product of the specific costs of carbo-
\end{abstract}

hydrate export and the export rates, either measured on full-grown (primary) leaves of potato and bean or derived from the literature. These export costs account, on average, for $29 \%$ of the dark respiration rate in starch-storing species. We conclude that nocturnal carbohydrate export is a major energy-requiring process in starch-storing species.

Key words: Carbohydrate export, leaf dark respiration, nitrogen concentration, respiratory costs, specific energy cost.

\section{Introduction}

The rate of dark respiration of leaves is often positively correlated to their nitrogen concentration (De Visser et al., 1992; Makino and Osmond, 1991; Pons et al., 1989; Van der Werf et al., 1994). Lambers et al. (1989) hypothesized that this relationship is associated with energy costs for (i) export of carbohydrates and (ii) protein turnover. In starch-storing species, nocturnal carbohydrate export involves the transformation of starch in the chloroplast to sucrose in the cytosol and the subsequent phloem loading of this sucrose. Phloem loading of sucrose is an active process (Gardner and Peel, 1972; Geiger, 1975, and references therein). Protein turnover involves the synthesis of new proteins not resulting in an increase

\footnotetext{
${ }^{4}$ Present address and to whom correspondence should be sent: Department of Horticulture, 103 Tyson Building, University Park, State College, PA 16802, USA. Fax: +18148636139.
} 


\section{Bouma et al.}

of the protein concentration. De Visser et al. (1992) calculated that protein turnover can account for the relationship between dark respiration and nitrogen concentration of leaves. However, there are reasons to hypothesize that, in addition to protein turnover, the energy cost involved in the export of carbohydrate also contributes to this relationship. Firstly, the costs of protein turnover may vary, in proportion to the degradation constants, by a factor of 20 (Bouma et al., 1994; De Visser et al., 1992). Secondly, photosynthesis and thus carbohydrate availability increase with the nitrogen concentration of the leaf, due to a higher photosynthetic capacity (Evans, 1983, 1989; Makino and Osmond, 1991; Nátr, 1975). If the energy costs involved in the export of carbohydrate do not affect the relationship between dark respiration and nitrogen concentration of leaves, these costs might still contribute significantly to the overall dark respiration of leaves. For example, the positive correlation between the rate of leaf dark respiration and the level of irradiation during the preceding photoperiod (Irving and Silsbury, 1988; Mullen and Koller, 1988) has been ascribed to the energy costs for the export of carbohydrates (Irving and Silsbury, 1988).

The aim of the present study is to assess the potential contribution of the energy costs of nocturnal carbohydrate export from mature source leaves to the fraction of dark respiration correlating with leaf nitrogen concentration and to the overall dark respiration rate of leaves grown with an optimal nitrogen supply. To this end, we determined (1) the relationships between nitrogen concentration of leaves and both leaf dark respiration and photosynthesis, (2) nocturnal carbohydrate-export rates from leaves with an optimal nitrogen supply, and (3) the specific costs of carbohydrate export.

\section{Materials and methods}

\section{Plant material and growth conditions}

Experiments were carried out with youngest full-grown leaves of potato (Solanum tuberosum L. cv. Alcmaria) and primary leaves of bean (Phaseolus vulgaris L. cv. Berna). Potato plants were propagated by in vitro culture (Bouma et al., 1992) and bean plants were grown from seeds (Bouma et al., 1994). Growth conditions and objectives of the individual experiments are summarized in Table 2. Plants were grown in a nutrient solution containing macro-nutrients at $1 / 2$ strength according to Hoagland and Snyder (1933) and micro-nutrients at $1 / 2$ strength according to Lewis and Powers (1941) with iron as Fe(III)-EDTA.

\section{The correlation of photosynthesis and dark respiration with leaf-nitrogen concentration $(\alpha)$}

Table 1 gives a list of the abbreviations used in the text with their corresponding units. The effect of the leaf organic nitrogen concentration on dark respiration $\left(\alpha, \mathrm{nmol} \mathrm{CO}_{2}\right.$ (mmol organic nitrogen $)^{-1} \mathrm{~s}^{-1}$ ) was described by a linear model:

$$
R_{\mathrm{d}}=a \times N_{\text {org }}+R_{\mathrm{r}}
$$

where $R_{\mathrm{d}}$ is the dark respiration ( $\mathrm{nmol} \mathrm{CO} \mathrm{CO}^{-2} \mathrm{~s}^{-1}$ ), $N_{\text {org }}$ is organic nitrogen concentration ( $\mathrm{mmol}$ organic nitrogen $\mathrm{m}^{-2}$ ) and $R_{\mathrm{r}}$ is a constant rest component of respiration $(\mathrm{nmol} \mathrm{CO}$ $\mathrm{m}^{-2} \mathrm{~s}^{-1}$ ). The relationship between photosynthesis and nitrogen concentration was described by a similar equation. Respiration and photosynthesis rates were measured under growth conditions (Table 2), on primary leaves of 17-20-(experiments bl and b2) and 21-24-(experiment b3) d-old bean plants. A range of leaf-nitrogen concentrations was obtained by daily supply of nitrogen at different relative nitrate addition rates $(R A R)$ to aerated $\mathrm{N}$-free nutrient solution $(R A R=0.05,0.085,0.115$, and $0.15 \mathrm{~d}^{-1}$; after Ingestad, 1979). In this solution, calcium and potassium were available at half the normal strength, as $\mathrm{CaCl}_{2}$ and $\mathrm{KH}_{2} \mathrm{PO}_{4}$ or $\mathrm{KCl}$, respectively. Nitrate was added as $\mathrm{Ca}\left(\mathrm{NO}_{3}\right)_{2}$ and $\mathrm{KNO}_{3}$ in the ratio present in the standard nutrient solution.

\section{Experimental estimation of the specific energy costs for carbohydrate export $\left(\mathrm{E}_{e}\right)$}

The specific costs for carbohydrate export $\left(E_{\mathrm{e}} ; \mathrm{mol} \mathrm{CO}_{2}[\mathrm{~mol}\right.$ sucrose] ${ }^{-1}$ ) were estimated by analysing the linear regression of dark respiration rate $\left(R_{\mathrm{d}} ; \mathrm{nmol} \mathrm{CO} \mathrm{Cm}^{-2} \mathrm{~s}^{-1}\right)$ on the nocturnal carbohydrate export rate $\left(C_{\mathrm{e}} ; \mathrm{nmol}\right.$ sucrose $\left.\mathrm{m}^{-2} \mathrm{~s}^{-1}\right)$ :

$$
R_{\mathrm{d}}=E_{\mathrm{e}} \times C_{\mathrm{e}}+R_{\mathrm{r}}
$$

where $R_{\mathrm{r}}$ is a constant rest component of respiration (nmol $\mathrm{CO}_{2} \mathrm{~m}^{-2} \mathrm{~s}^{-1}$ ). Respiration was measured on full-grown potato leaves with different carbohydrate export rates, assuming

Table 1. List of abbreviations

\begin{tabular}{|c|c|c|}
\hline Abbreviation & Description & Unit \\
\hline$\alpha$ & $\begin{array}{l}\text { Slope of the relationship of respiration versus organic nitrogen } \\
\text { concentration }\end{array}$ & $\mathrm{nmol} \mathrm{CO} 2(\mathrm{mmol} \mathrm{N} \mathrm{org})^{-1} \mathrm{~s}^{-1}$ \\
\hline$a_{\mathrm{e}}$ & Fraction of $\alpha$ explained by carbohydrate export only & - \\
\hline$C_{\mathrm{e}}$ & (Observed) carbohydrate export rate & nmol sucrose $m^{-2} s^{-1}$ \\
\hline$E_{\mathrm{e}}$ & Specific energy costs for carbohydrate export & $\begin{array}{l}\mathrm{mol} \mathrm{CO}_{2}{\text { (mol sucrose })^{-1} \text { or }}^{\text {mol ATP }(\mathrm{mol} \text { sucrose })^{-1}}\end{array}$ \\
\hline$N_{\text {org }}$ & Organic nitrogen concentration & $\mathrm{mmol} \mathrm{m}-2$ \\
\hline$\Delta N_{\text {org }}$ & Range of organic nitrogen concentrations underlying $\alpha$ & $\mathrm{mmol} \mathrm{m}-2$ \\
\hline & Photosynthesis rate & $\mathrm{nmol} \mathrm{CO} \mathrm{m}^{-2} \mathrm{~s}^{-1}$ \\
\hline$R A R$ & Relative addition rate & $\mathrm{d}^{-1}$ \\
\hline$R_{\mathrm{d}}$ & (Observed) dark respiration rate & $\mathrm{nmol} \mathrm{CO} \mathrm{m}^{-2} \mathrm{~s}^{-1}$ \\
\hline$R_{\mathrm{e}}$ & Dark respiration rate associated with carbohydrate export & $\mathrm{nmol} \mathrm{CO} \mathrm{m}^{-2} \mathrm{~s}^{-1}$ \\
\hline$R_{\mathrm{r}}$ & Constant rest component of respiration & nmol $\mathrm{CO}_{2} \mathrm{~m}^{-2} \mathrm{~s}^{-1}$ \\
\hline
\end{tabular}

If indicated in the text that the values are expressed on a dry weight basis, the $\mathrm{m}^{-2}$ should be substituted by $(\mathrm{g} \mathrm{dw})^{-1}$ in the units given below. 
Table 2. The parameters derived and growth conditions in the present experiments

For potato, the youngest full-grown (YFG) leaves were used. The abbreviations used for the different light types are: $d=$ natural daylight in the greenhouse, F \& I= fluorescent light (Philips TLD36W/54) and incandescent light (Pope $60 \mathrm{~W}$ ) in a ratio of 12:1, H=HPI light (Philips HPI/T $400 \mathrm{~W})$. The relative humidity was $70-75 \%$.

\begin{tabular}{|c|c|c|c|c|c|c|c|}
\hline \multirow[t]{2}{*}{ Parameters } & \multirow[t]{2}{*}{ Experiment } & \multirow[t]{2}{*}{ Species } & \multirow{2}{*}{$\begin{array}{l}\text { Leaf age } \\
\text { (d) }\end{array}$} & \multicolumn{3}{|l|}{ Light } & \multirow{2}{*}{$\begin{array}{l}\text { Temperature } \\
\left({ }^{\circ} \mathrm{C}\right)\end{array}$} \\
\hline & & & & $\begin{array}{l}\text { Period } \\
\text { (h) }\end{array}$ & $\begin{array}{l}P P F D \\
\left(\mu \mathrm{mol} \mathrm{m}{ }^{-2} \mathrm{~s}^{-1}\right)\end{array}$ & Type & \\
\hline$a$ & $\mathrm{~b} 1$ and $\mathrm{b} 2$ & Bean & $17-20$ & 16 & 500 & $\mathrm{H}$ & 21 \\
\hline$a$ & b3 & Bean & $21-24$ & 16 & 500 & $\mathrm{H}$ & 21 \\
\hline$E_{\mathrm{e}}, C_{\mathrm{e}}$ & $\mathrm{P} 1$ & Potato & YFG & 14 or 9 & & $\mathrm{~d} \& \mathrm{H}$ & 20 \\
\hline$C_{\mathrm{e}}$ & $\mathrm{P} 0$ & Potato & YFG & 12 or 18 & 240 & F \& I & 18 \\
\hline \multirow[t]{2}{*}{$C_{\mathrm{e}}$} & b4 & Bean & $14-17$ & 16 & 240 & $F \& I$ & 21 \\
\hline & & & & 16 & 500 & $\mathrm{H}$ & 21 \\
\hline$C_{\mathrm{e}}$ & b5 & Bean & $17-20$ & 16 & 500 & $\mathrm{H}$ & 23 \\
\hline
\end{tabular}

constant costs for other processes. Carbohydrate export was varied by changing the root temperature (i.e. changing the sink activity; cf. Verkleij and Challa [1988] and references therein). In a preliminary experiment (P0; Table 2$)$, root temperature and leaf respiration rate were correlated, but $E_{\mathrm{e}}$ could not be estimated as the variation in carbohydrate concentration between potato leaves of a single plant was larger than the decrease due to carbohydrate export. In the next experiment (P1), nocturnal export rates were derived as the decrease in specific dry weight of samples of the youngest full-grown leaves on plants with root temperatures changed from 7.5 to $20^{\circ} \mathrm{C}$ and vice versa, after subtracting the carbohydrates respired. In these leaves, net export of amino acids was assumed to be negligible. Nocturnal respiration rates of these leaves were determined simultaneously, at a constant leaf temperature. Leaf discs were sampled during the dark period from the leaf fraction outside the respiration cuvette.

\section{Theoretical estimation of the specific energy cost for carbohydrate export $\left(\mathrm{E}_{e}\right)$}

The specific cost for carbohydrate export $\left(E_{\mathrm{e}}\right)$ is calculated from the fraction of the carbohydrates exported that originates from starch $\left(f_{\mathrm{st}}\right)$, the specific energy costs of the conversion of starch in the chloroplast to sucrose in the cytosol $\left(E_{\mathrm{st}} ; \mathrm{mol} \mathrm{CO}_{2}[\mathrm{~mol}\right.$ sucrose $\left.]^{-1}\right)$ and the specific costs of sucrose loading into the phloem $\left(E_{\mathrm{pl}}\right.$ mol $\left.\left.\mathrm{CO}_{2}[\mathrm{~mol} \text { sucrose }]^{-1}\right)\right)$.

$$
E_{\mathrm{e}}=f_{\mathrm{st}} \times\left(E_{\mathrm{st}}+E_{\mathrm{p} 1}\right)+\left(1-f_{\mathrm{st}}\right) \times E_{\mathrm{pl}} .
$$

In starch-storing species, the nocturnal carbohydrate export originates for $70-100 \%$ from starch (i.e. $f_{\text {st }}=0.7$ to 1.0 ; e.g. data in Caspar et al., 1985; Fondy and Geiger, 1982; Grange, 1985; Kalt-Torres et al.,1987). The remaining carbohydrates may originate from, for example, sucrose in the cytosol. Carbon moves to the cytosol from the chloroplast as (1) triosephosphate, (2) hexose, or as (3) the disaccharide maltose (Beck, 1985; Servaites et al., 1989; Stitt, 1990). All pathways from starch in the chloroplast to sucrose in the cytosol require 3 ATP per sucrose, except when maltose is degraded by maltose phosphorylase (i.e. $E_{\text {st }}=2$ ATP per sucrose; Beck, 1985). These values are based on the assumption that hexoses and maltose cross the chloroplast envelope passively, down their concentration gradient resulting from the continuous biochemical conversion. In the present species, phloem loading is expected to occur apoplastically (Van Bel, 1992, 1993, and personal communication). The specific costs associated with apoplastic phloem loading $\left(E_{\mathrm{pl}}\right)$ are 1 ATP per sucrose in plasma membrane vesicles (Slone and Buckhout, 1991). Thus, using equation 3, $E_{\mathrm{e}}$ is found to range from 2.4 to $4 \mathrm{~mol} \mathrm{ATP} \mathrm{(mol} \mathrm{sucrose)}{ }^{-1}$.

\section{Measurements of carbohydrate export $\left(\mathrm{C}_{\mathrm{e}}\right)$ and simultaneous respiration rates $\left(\mathrm{R}_{d}\right)$}

Nocturnal carbohydrate export rates $\left(C_{\mathrm{e}} ; \mathrm{nmol}\right.$ sucrose $\left.\mathrm{m}^{-2} \mathrm{~s}^{-1}\right)$ were determined on bean leaves, which accumulate significant amounts of starch (Plaut et al., 1987). Our treatments to manipulate carbohydrate export rates were insufficient to obtain a range suitable for estimating $E_{\mathrm{e}}$.

In experiment $\mathrm{b} 4$, dark respiration was monitored during three successive parts $(2.67 \mathrm{~h})$ of the normal dark period $(8 \mathrm{~h})$, using different plants for each period (Table 2). At the end of each period, the leaf used for the respiration measurements and the control leaf of each plant were harvested. Export rates during the three dark periods were derived from the decrease in carbohydrate concentration between succeeding periods, after subtraction of the carbohydrates respired.

In experiment b5, the shoot was pruned just above the primary leaves, and a metal cooler $\left(4^{\circ} \mathrm{C}\right)$ was placed around the stem directly under the primary leaves, at the start of the light period. The leaf temperature was kept constant. The light period preceding the respiration measurements was 2 or $16 \mathrm{~h}$. At the onset of the dark period, one leaf per plant was harvested, and stem coolers were removed. Respiration was followed on the remaining leaf, which was harvested $2 \mathrm{~h}$ later. Dark export rates were derived from the differences in carbohydrate concentration between the leaves, after subtracting the carbohydrates respired.

\section{Calculations on the contribution of the energy costs of carbohydrate export to $\alpha$ and $R_{d}$}

The fraction $a_{\mathrm{e}}$ of the effect of leaf organic nitrogen concentration on dark respiration ( $\alpha$; see eq. 1$)$ that may be explained by the energy costs involved in carbohydrate export was calculated from the specific costs for export $\left(E_{\mathrm{e}} ; \mathrm{mol} \mathrm{CO}_{2}[\mathrm{~mol} \mathrm{sucrose}]^{-1}\right)$ and the decrease in carbohydrate export rate $\left(\Delta C_{\mathrm{e}} ; \mathrm{nmol}\right.$ sucrose $\left.\mathrm{m}^{-2} \mathrm{~s}^{-1}\right)$ at decreasing organic nitrogen concentration $\left(\Delta N_{\text {org }} ;\right.$ mmol organic nitrogen $\left.\mathrm{m}^{+2}\right)$ :

$$
a_{\mathrm{e}}=\left(E_{\mathrm{e}} \times \Delta C_{\mathrm{e}} / \Delta N_{\text {org }}\right) / \alpha .
$$

The upper limit of $a_{\mathrm{e}}$ was calculated by estimating $\Delta C_{\mathrm{e}}$ as the carbohydrate export rate at optimal nitrogen suply $\left(C_{\mathrm{e}}\right.$; nmol sucrose $\mathrm{m}^{-2} \mathrm{~s}^{-1}$ ), i.e. assuming a zero export rate at the lowest organic nitrogen concentration. 
The respiration involved in carbohydrate export $\left(R_{\mathrm{e}} ; \mathrm{nmol}\right.$ $\mathrm{CO}_{2} \mathrm{~m}^{-2} \mathrm{~s}^{-1}$ ) was obtained from the specific costs for carbohydrate export $\left(E_{e} ; \mathrm{mol}\right.$ ATP $\left.[\mathrm{mol} \text { sucrose }]^{-1}\right)$, and the carbohydrate-export rates $\left(C_{\mathrm{e}}\right.$; nmol sucrose $\left.\mathrm{m}^{-2} \mathrm{~s}^{-1}\right)$ determined on the youngest full-grown leaves of potato (experiments $\mathrm{P} 0$ and $\mathrm{P} 1$ ) and primary leaves of bean (experiments b4 and b5) with an optimal nitrogen supply:

$$
R_{\mathrm{e}}=E_{\mathrm{e}} \times C_{\mathrm{e}} .
$$

\section{Analysis of leaf development}

In bean, expansion of individual primary leaves was monitored non-destructively, with a video camera (SONY AVC $3250 \mathrm{CE}$ Japan) and monitor (SONY PVM 90 CE, Japan) connected to an integrator (TFDL nr 720314, Wageningen, the Netherlands) to establish the full-grown stage of the leaf. For potato, the youngest full-grown leaves were selected, using older leaves as a reference.

\section{Dark respiration and photosynthesis measurements}

Dark respiration and photosynthesis were measured on leaves of intact plants by infra-red gas analysis (IRGA; Analytical Development Co., Type 225-2B-SS, Hoddesdon, UK) as described by Louwerse and Van Oorschot (1969) with computerized control and continuous data processing. To enable reliable determination of nocturnal $\mathrm{CO}_{2}$-production, flow rates were low $\left(\geqslant 0.12 \mathrm{~m}^{3} \mathrm{~h}^{-1}\right.$ or $\left.0.033 \times 10^{43} \mathrm{~m}^{3} \mathrm{~s}^{-1}\right)$ and leaf area was large $\left(25-64 \mathrm{~cm}^{2}\right)$. During these dark respiration measurements, leaf temperature was closely regulated by the air temperature, as there was no increment due to light interception. The enclosure of the leaf in the respiration cuvette had no effect on the concentration of total reducing soluble carbohydrates and starch in the leaf (data not shown).

\section{Chemical analyses}

Plant material was dried at a temperature of $70^{\circ} \mathrm{C}$, in an oven with forced ventilation. Total soluble carbohydrates were extracted by 10 min boiling in demineralized water, which does not affect cell walls. Reducing monosaccharides were determined in the extract by titration with sodium thiosulphate (AOAC, 1984). The total soluble carbohydrates were obtained by hydrolysing the extract by boiling in $0.05 \mathrm{M} \mathrm{H}_{2} \mathrm{SO}_{4}$ (i.e. $0.25 \mathrm{ml}$ $5 \mathrm{M} \mathrm{H}_{2} \mathrm{SO}_{4}$ in $25 \mathrm{ml}$ extract), for $30 \mathrm{~min}$. The resulting reducing monosaccharides were determined by titration (AOAC, 1984). To determine starch, the plant material was extracted twice with $40 \%$ ethanol $\left(15 \mathrm{~min}, 20^{\circ} \mathrm{C}\right)$ to remove low molecular weight carbohydrates. The residue was boiled for $1 \mathrm{~h}$ at $125^{\circ} \mathrm{C}$ at $0.13 \mathrm{MPa}$. Starch was enzymatically hydrolysed for $1 \mathrm{~h}$ at $60^{\circ} \mathrm{C}$ by amylog osidase (EC 3.2.1.3; Merck, Darmstadt BRD) containing negligible sugar contamination. Subsequently, the glucose formed was determined by titration (AOAC, 1984). Starch concentration was expressed in $\mathrm{mg} \mathrm{CH}_{2} \mathrm{O}(\mathrm{g} \mathrm{dw})^{-1}$.

The organic nitrogen concentration $\left(N_{\text {org }}\right)$ of leaves of various ages was determined as the difference between the total nitrogen and $\mathrm{NO}_{3}^{-}$-nitrogen. Total nitrogen and $\mathrm{NO}_{3}^{-}$-nitrogen were determined by $\mathrm{CHN}$ analysis on a Heraeus CHN-rapid (Hanau, Germany) and a TRAACS 800 continuous flow system (Bran and Luebbe, Germany), respectively.

\section{Statistics}

The statistical package GENSTAT 5 (Payne, 1987) was used for the linear regression analysis.

\section{Results}

The correlation of photosynthesis and dark respiration ( $\alpha$ ) with leaf-nitrogen concentration

Photosynthesis correlated strongly with the organic nitrogen concentration of the primary leaves of bean (Fig. 1). The slope of the regression lines $\left(0.11 \mu \mathrm{mol} \mathrm{CO} \mathrm{CO}_{2}(\mathrm{mmol}\right.$ organic $\mathrm{N})^{-1} \mathrm{~s}^{-1}$ ) was similar for both the 17-20-d-old and the 21-24-d-old leaves, whereas the intercepts were -0.64 and $-1.74 \mu \mathrm{mol} \mathrm{CO}_{2} \mathrm{~m}^{-2} \mathrm{~s}^{-1}$, respectively. A correlation of photosynthesis and organic nitrogen concentration has generally been found for several species, whereas a relationship between respiration and organic nitrogen concentration is less often studied (references in the Introduction). The regression of respiration on organic nitrogen concentration for 17-20-d-old and 21-24-d-old primary leaves (eq. 1), also yielded a strong correlation (Fig. 2), both on a leaf area and a leaf dry weight basis (Table 3 ).

\section{Measurements of carbohydrate export $\left(\mathrm{C}_{e}\right)$ and simultaneous respiration rates $\left(\mathrm{R}_{d}\right)$}

For both potato and bean, the carbohydrate concentration in the leaf decreased mainly due to export, whereas the effect of respiration was at least a factor of 2 lower (Table 4). The strong decrease in carbohydrate concentration in experiment b4 can at least be partly ascribed to growth, as up to day 17 the primary leaves of bean continued to expand (data not shown). For this reason, in experiment b4 the export rate may have been overestimated. In all other experiments the leaves did not grow.

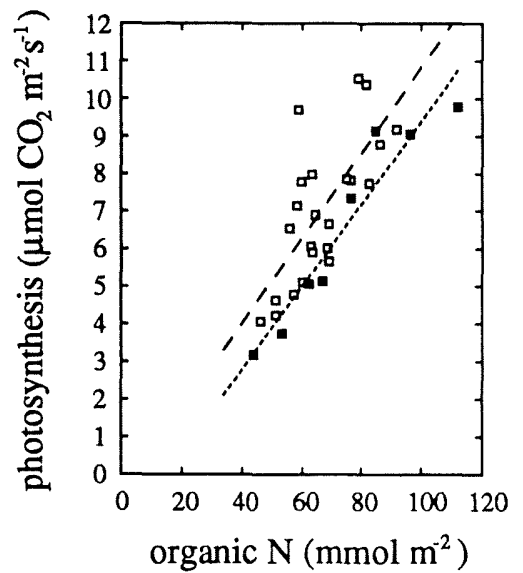

Fig. 1. Relationship between photosynthesis rate and organic nitrogen concentration $\left(N_{\text {org }}\right)$ for 17-20 ( $\square$ ) and 21-24 (ם)-d-old primary leaves of bean. The lines indicate the regression equations: $P=$ $0.11 \times N_{\text {org }}-0.64(r=0.72 ; \mathrm{df}=21)$ and $P=0.11 \times N_{\text {org }}-1.74(r=0.96$; $\mathrm{df}=6)$. Each symbol represents an independent measurement on an individual plant at growth conditions (Table 2). Different nitrogen concentrations were obtained by nitrogen supply at different relative addition rates. 
Table 3. The fraction of a (i.e. the effect of the leaf organic nitrogen concentrations on the dark respiration) that cun be explained by carbohydrate export rates $\left(a_{e}\right)$, for a range of 50-100 mmol organic $\mathrm{N} \mathrm{m}^{-2}$ in bean leaves

To obtain the upper limit of $a_{\mathrm{e}}$, we used specific cost for carbohydrate export $\left(E_{\mathrm{e}}\right)$ of $1.2 \mathrm{~mol} \mathrm{CO}_{2}$ per mol sucrose. All regressions were significant ( $r$ from above to below was $0.73,0.82,0.62$, and 0.53 ; df is 30 and 14 for 17-20 [exp. bl plus b2] and 21-24 [exp. b3]-d-old leaves, respectively).

\begin{tabular}{|c|c|c|c|c|}
\hline \multirow{2}{*}{$\begin{array}{l}\text { Age } \\
\text { (d) }\end{array}$} & \multicolumn{3}{|c|}{ Regression of leaf respiration versus organic nitrogen (cf. eq. 1) } & \multirow{2}{*}{$\begin{array}{l}a_{\mathrm{e}} \text { (cf. eq. } 4 \text { ) } \\
\text { upper limit }\end{array}$} \\
\hline & Basis & $\left.\stackrel{\alpha}{(\mathrm{nmol} \mathrm{CO}} \mathrm{CO}_{2}[\mathrm{mmol} \text { organic } \mathrm{N}]^{-1} \mathrm{~s}^{-1}\right)$ & $\begin{array}{l}R_{\mathrm{r}} \\
\left(\mathrm{nmol} \mathrm{CO}_{2}\left[\mathrm{~m}^{2} \text { or } \mathrm{g} \mathrm{dw}\right]^{-1} \mathrm{~s}^{-1}\right)\end{array}$ & \\
\hline \multirow[t]{2}{*}{$17-20$} & $\mathrm{~m}^{2}$ & 8.8 & 331 & 0.54 \\
\hline & $\mathrm{g} \mathrm{dw}$ & 11.3 & 3.6 & 0.42 \\
\hline \multirow[t]{2}{*}{$21-24$} & $\mathrm{~m}^{2}$ & 5.3 & 655 & 0.89 \\
\hline & $\mathrm{g} \mathrm{dw}$ & 4.4 & 13.2 & 1.07 \\
\hline
\end{tabular}

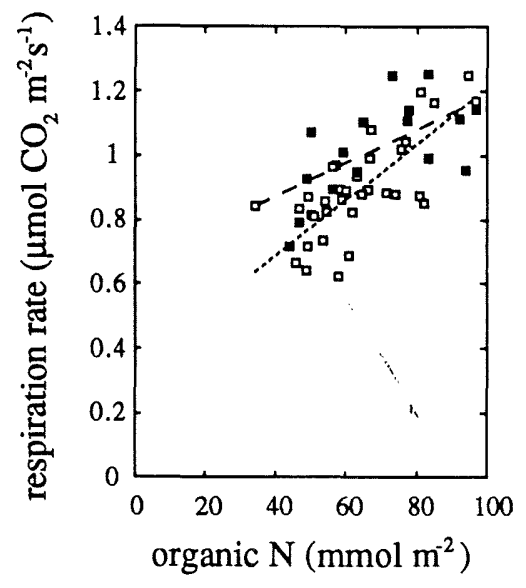

Fig. 2. Relationship between respiration rate and organic nitrogen

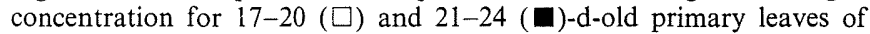
bean. The lines indicate the regression equations: $R_{\mathrm{d}}=8.8 \times N_{\mathrm{org}}+331$ $(r=0.73 ; \mathrm{df}=30)$ and $R_{\mathrm{d}}=5.3 \times N_{\text {org }}+655(r=0.62 ; \mathrm{df}=14)$ with the slope $(a)$ and the intercept $\left(R_{\mathrm{r}} ;\right.$ all units cf. eq. 1). Each symbol represents an independent determination on an individual plant at growth conditions (Table 2). Different nitrogen concentrations were obtained by nitrogen supply at different relative addition rates.

\section{Specific energy costs for carbohydrate export $\left(\mathrm{E}_{e}\right)$; experimental and theoretical estimates}

Linear regression of the respiration rate on carbohydrate export rate (eq. 2) yielded a value of $0.7 \pm 0.2 \mathrm{~mol} \mathrm{CO}$ (mol sucrose) ${ }^{-1}$ for the specific cost of carbohydrate export (Fig. 3 derived from experiment P1). The theoretical estimate of these specific costs $\left(E_{\mathrm{e}}\right)$ ranges from 2.4 to 4 mol ATP per mol sucrose (calculation in Materials and methods). Regarding the values generally observed for the ATP $/ \mathrm{O}_{2}$-ratio ( 6 to 4 ; e.g. Table 2 in Lambers et al., 1983) and the $R Q$ (1 to 1.2, but most often close to 1 ; Yemm, 1965) of full-grown leaves, this equals a range of $E_{\mathrm{e}}$ from 0.4 to $1.2 \mathrm{~mol} \mathrm{CO}_{2}$ per mol sucrose. Thus, although the correlation in Fig. 3 is not.strong, the value of $E_{\mathrm{e}}$ agreed well with theoretical estimates.

\section{Calculations of the contribution of the energy costs of carbohydrate export to $\alpha$ : upper limits}

The effect of leaf organic-nitrogen concentration on leaf dark respiration is characterized by the regression coef-

Table 4. The percentage dark respiration explained by the cost of carbohydrate export for potato (P0 and P1) and bean (b4 and b5)

$R_{\mathrm{e}}$ was calculated according to equation 5, using the theoretically derived range of the specific cost for carbohydrate export of 0.4 to $1.2 \mathrm{~mol} \mathrm{CO}_{2}$ per mol sucrose. To express the rate of respiration and carbohydrate export measured in the preliminary potato experiment ( $\mathrm{P} 0$ ) on a leaf area basis, we used a specific leaf area of $47 \mathrm{~m}^{2}(\mathrm{~kg} \mathrm{dw})^{-1}$ (Bouma et al., 1992). The decrease in carbohydrate concentration due to export was calculated as the difference between the total decrease and respiratory losses. The export rate calculated in experiment b4 $\left(^{*}\right)$ might have been overestimated, as leaves were still expanding.

\begin{tabular}{|c|c|c|c|c|c|c|}
\hline \multirow[t]{2}{*}{ Experiment } & \multirow[t]{2}{*}{ Treatment } & \multicolumn{2}{|l|}{ Dark respiration } & \multicolumn{3}{|c|}{ Decrease in carbohydrate concentration } \\
\hline & & $\begin{array}{l}\text { Total }\left(R_{\mathrm{d}}\right) \\
\left(\mathrm{nmol} \mathrm{CO} \mathrm{m}^{-2} \mathrm{~s}^{-1}\right)\end{array}$ & $\begin{array}{l}\text { Export }\left(R_{\mathrm{e}}\right) \\
(\%)\end{array}$ & $\begin{array}{l}\text { Total } \\
\left(\mathrm{nmol} \text { sucrose } \mathrm{m}^{-2} \mathrm{~s}^{-1}\right)\end{array}$ & $\begin{array}{l}\text { Export } \\
(\%)\end{array}$ & $\begin{array}{l}\text { Respiration } \\
(\%)\end{array}$ \\
\hline P0 & & 379 & $7-20$ & 96 & 67 & 33 \\
\hline \multirow[t]{4}{*}{$\mathrm{P} 1$} & $20 \rightarrow 20$ & 676 & $17-51$ & 343 & 84 & 16 \\
\hline & $20 \rightarrow 7.5$ & 688 & $12-37$ & 272 & 79 & 21 \\
\hline & $7.5 \rightarrow 20$ & 526 & $9-26$ & 158 & 72 & 28 \\
\hline & $7.5 \rightarrow 7.5$ & 602 & $8-23$ & 168 & 70 & 30 \\
\hline \multirow[t]{2}{*}{ b4 } & $\mathrm{HL}$ & 1156 & $18-54^{*}$ & 616 & $84^{*}$ & 16 \\
\hline & LL & 719 & $18-55^{*}$ & 392 & $85^{*}$ & 15 \\
\hline \multirow[t]{2}{*}{ b5 } & $2 \mathrm{~h}$ light & 1072 & $8-23$ & 296 & 70 & 30 \\
\hline & $16 \mathrm{~h}$ light & 1022 & $7-22$ & 272 & 69 & 31 \\
\hline Average & & 760 & $12-35$ & 290 & 76 & 24 \\
\hline
\end{tabular}




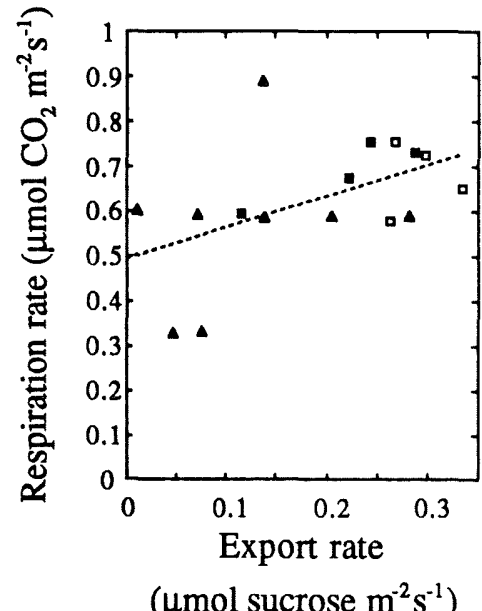

Fig. 3. Relationship between respiration rate and carbohydrate export for full-grown leaves of potato. Roots were transferred from 20 to $20^{\circ} \mathrm{C}(\square), 20$ to $7.5^{\circ} \mathrm{C}(\boldsymbol{\square}), 7.5$ to $20^{\circ} \mathrm{C}(\triangle)$, and 7.5 to $7.5^{\circ} \mathrm{C}(\boldsymbol{\Delta})$ The dashed line indicates the regression equation: $R_{\mathrm{d}}=0.70 \times C_{\mathrm{e}}+0.49$ $(r=0.498 ; \mathrm{df}=14)$. Each symbol represents an independent determination on an individual plant.

ficient $\alpha$ (see eq. 1). The fraction $a_{\mathrm{e}}$ of $\alpha$ that can be explained by respiratory energy costs associated with carbohydrate export was calculated using equation 4 , as described in Materials and methods. The decrease in nocturnal carbohydrate export rate $\left(\Delta C_{\mathrm{e}}\right)$ was taken to be equal to the export rate observed in experiment b5 (i.e. $197 \mathrm{nmol}$ sucrose $\mathrm{m}^{-2} \mathrm{~s}^{-1}$; after Table 4), for a decrease of the organic nitrogen concentration $\left(\Delta N_{\text {org }}\right)$ with approximately $50 \mathrm{mmol} \mathrm{m}^{-2}$ (data values in Figs 1 and 2). Table 3 shows the upper limits of $a_{\mathrm{e}}$, based on the highest estimate of the specific costs of carbohydrate export $\left(E_{\mathrm{e}}=1.2 \mathrm{~mol} \mathrm{CO} \mathrm{CO}_{2}[\mathrm{~mol} \text { sucrose }]^{-1}\right)$. When using the experimentally derived estimate of $E_{\mathrm{e}}\left(0.7 \mathrm{~mol} \mathrm{CO}_{2}\right.$ [mol sucrose $]^{-1}$ ), the value for $a_{\mathrm{e}}$ ranges from 0.24 to 0.31 and 0.52 to 0.63 , for $17-20$-d-old and $21-24-d-o l d$ leaves, respectively. We conclude that carbohydrate export may account for a significant part of the effect of leaf organic nitrogen concentration on dark respiration $(a)$, in the present tissue ( $a_{\mathrm{e}}$ in Table 3$)$.

\section{Calculations of the contribution of the energy costs of carbohydrate export to $R_{d}$ : upper and lower limits}

Combining the calculated range of the specific costs for carbohydrate export $\left(E_{\mathrm{e}}=0.4-1.2 \mathrm{~mol} \quad \mathrm{CO}_{2} \quad[\mathrm{~mol}\right.$ sucrose $\left.]^{-1}\right)$ with the observed rates of carbohydrate export $\left(C_{\mathrm{e}}\right.$; cf. eq. 5), leads to the conclusion that export costs account for approximately $7-51 \%$ of the dark respiration rates $\left(R_{\mathrm{e}}\right.$ in Table 4$)$. When using the experimentally derived estimate of $E_{\mathrm{e}}\left(0.7 \mathrm{~mol} \mathrm{CO}_{2} \quad[\mathrm{~mol}\right.$ sucrose $]^{-1}$ ), the average value of this fraction is $20 \%$.
Thus, carbohydrate export can account for a significant part of $R_{\mathrm{d}}$.

\section{Discussion}

\section{Specific energy costs of carbohydrate export $\left(\mathrm{E}_{e}\right)$}

Estimates of the specific cost of carbohydrate export $\left(E_{\mathrm{e}}\right)$ are required to determine the contribution of the energy costs of nocturnal carbohydrate export to leaf dark respiration rate $\left(R_{\mathrm{d}}\right)$. The estimate of $E_{\mathrm{e}}$ obtained by linear regression $\left(0.7 \mathrm{~mol} \mathrm{CO}_{2}[\mathrm{~mol} \text { sucrose }]^{-1}\right.$; cf. eq. 2$)$ was within the theoretically calculated range $(0.4-1.2 \mathrm{~mol}$ $\mathrm{CO}_{2}$ [mol sucrose $]^{-1}$ ). Table 5 compares the present estimate of $E_{\mathrm{e}}$ to the values in the literature. These literature values were obtained by (1) linear regression of respiration rate versus carbohydrate export rate, (2) dividing the export rate by the total respiration rate or (3) dividing the export rate by the respiration rate corrected for maintenance respiration as estimated by the dark-decay method. Method 2 yields an upper limit of the specific costs of export, as all respiration is ascribed to carbohydrate export. Method 3 lacks power, as it is largely unknown which processes underlie the respiration determined by the dark-decay approach. In the present experiment (P1; see Table 2) we used Method 1. The sometimes observed asynchronous time-course of the respiration and export rates during the dark period (Grange, 1985), might be seen as a possible objection against Method 1 (Hendrix and Grange, 1991). Apparently, the activities of the various energy-requiring processes in the leaf do not always have the same time pattern during the dark period. Even starch degradation and phloem loading do not necessarily occur synchronously. However, as long as the overall nocturnal energy demand of all processes other than carbohydrate export remains constant between treatments, it is valid to use average export and respiration rates. In our opinion, this is best achieved when the environmental conditions of all source leaves studied are similar (i.e. previous illumination period and light intensity, relative air humidity, temperature and $\mathrm{CO}_{2}$-concentration). Therefore, we varied the export (and respiration) rates of potato leaves by manipulating root temperatures. The average export and respiration rates of Grange (1985) agree with present experimental observations and the fitted regression line.

Most experimental estimates of the specific costs of carbohydrate export agree well with the theoretical values, despite the different methods used (Table 5). The high values for tomato (Ho and Thornley, 1978) and soybean cultivar Wells II (after Mullen and Koller, 1988) are difficult to explain. In many cases the energy costs for carbohydrate export would exceed the actual respiration rates when multiplying these high specific costs for carbohydrate export with the observed export rates shown in 
Table 5. Theoretical and experimental estimates of the specific costs for carbohydrate export in starch-storing species

The literature values were expressed on an ATP-basis using a combination of the $\mathrm{P} / \mathrm{O}_{2}$-ratio and $R Q$ of either 4 and 1.2 or 6 and 1 , respectively; these combinations give the maximum range. The specific cost of export based on Grange (1987) was derived by regression, using his unpublished respiration data of plants, 0, 4 and $8 \mathrm{~d}$ after transfer to high or low irradiance (personal communication, R.I. Grange). Hendrix and Grange (1991) calculated $E_{\mathrm{e}}$ from the values after $4 \mathrm{~h}$ in the dark, as presented by Fondy and Geiger (1982).

\begin{tabular}{|c|c|c|c|}
\hline \multicolumn{2}{|c|}{ Specific costs for carbohydrate export $\left(E_{\mathrm{e}}\right)$} & \multirow[t]{2}{*}{ Species } & \multirow[t]{2}{*}{ References } \\
\hline$\left(\mathrm{mol} \mathrm{CO}{ }_{2}\left[\mathrm{~mol} \mathrm{sucrose}^{-1}\right)\right.$ & $\left(\mathrm{mol} \mathrm{ATP}[\mathrm{mol} \text { sucrose }]^{-1}\right)$ & & \\
\hline \multicolumn{4}{|l|}{$E_{\mathrm{e}}=$ theoretically calculated } \\
\hline $0.4-1.2$ & $2.4-4.0$ & $\begin{array}{l}\text { Species with } \\
\text { apoplastic loading }\end{array}$ & Present paper \\
\hline \multicolumn{4}{|l|}{$E_{\mathrm{e}}=$ slope regression } \\
\hline 0.70 & $2.3-4.2$ & Potato & Present paper \\
\hline 0.79 & $2.6-4.7$ & Pepper & After Grange (1987) \\
\hline 1.20 & $4.0-7.2$ & Cotton & Hendrix and Grange (1991) \\
\hline 0.96 & $3.2-5.8$ & Barley & Hitz (1982) \\
\hline 2.64 & $8.8-15.8$ & Tomato & Ho and Thornley (1978) \\
\hline 0.47 & $1.6-2.8$ & $\begin{array}{l}\text { Soybean cv. } \\
\text { Amsoy } 71\end{array}$ & $\begin{array}{l}\text { After Mullen and Koller } \\
\text { (1988) }\end{array}$ \\
\hline 3.84 & $12.8-23.1$ & $\begin{array}{l}\text { Soybean cv. } \\
\text { Wells II }\end{array}$ & $\begin{array}{l}\text { After Mullen and Koller } \\
\text { (1988) }\end{array}$ \\
\hline \multicolumn{4}{|c|}{$E_{\mathrm{e}}=$ respiration rate/export rate } \\
\hline \multirow[t]{2}{*}{1.00} & $3.3-6.0$ & Sugar beet & $\begin{array}{l}\text { After Fondy and Geiger } \\
(1982) \text {, as derived by }\end{array}$ \\
\hline & $\therefore$ & & $\begin{array}{l}\text { Hendrix and Grange } \\
\text { (1991) }\end{array}$ \\
\hline \multirow[t]{2}{*}{$0.60-1.26$} & $2.0-7.6$ & Field bean & Calculation method 1 \\
\hline & , & & Irving and Silsbury (1988) \\
\hline \multicolumn{4}{|c|}{$E_{\mathrm{e}}=($ respiration rate - dark decay respiration $) /$ export rate } \\
\hline $0.60-0.77$ & $2.0-4.6$ & Field bean & $\begin{array}{l}\text { Calculation Method } 2 \text { in } \\
\text { Irving and Silsbury (1988) }\end{array}$ \\
\hline
\end{tabular}

Table 6. The reasons for these deviating results remain obscure, but may be additional energy-requiring processes, correlating with carbohydrate export. The good agreement between the theoretical range and most of the experimental data, indicate that the present theoretical range of the specific energy costs of carbohydrate export is a sound basis for calculating the contribution of the energy costs of carbohydrate export to $a$ and $R_{\mathrm{d}}$.

Table 6. The percentage dark respiration $\left(\mathrm{R}_{d}\right)$ explained by costs for carbohydrate export, for data derived from the literature on starch-storing species

The costs for carbohydrate export $\left(R_{\mathrm{e}}\right)$ were calculated using equation 5 , with $C_{\mathrm{e}}$ derived from the literature and a range of 0.4 to 1.2 mol $\mathrm{CO}_{2}$ per mol sucrose for $E_{\mathrm{e}}$.

\begin{tabular}{lcll}
\hline Dark respiration for export $\left(R_{\mathrm{e}}\right)$ & Species & Data recalculated after the references given \\
\hline$\left(\mathrm{nmol} \mathrm{CO} \mathrm{m}^{-2} \mathrm{~s}^{-1}\right)$ & $\left(\%\right.$ of $\left.R_{\mathrm{d}}\right)$ & & \\
\hline 98 & $9-27$ & Arabidopsis & Caspar et al. (1985), Fig. 1; Table 3 \\
177 & $23-69$ & Sugar beet & Fondy and Geiger (1982), Fig. 1a \\
$71-174$ & $12-78$ & Pepper & Grange (1985), Fig. 4; Table 2 \\
$8-180$ & $1-38$ & Cotton & Hendrix and Grange (1991), Fig. 6 \\
$171-343$ & $7-60$ & Cotton & Hendrix and Huber (1986), Fig. 1 \\
$310-388$ & $32-96$ & Field bean & Irving and Silsbury (1988), Fig. 1 \\
257 & $11-33$ & Maize & Kalt-Torres et al. (1987), Figs 1 and 2 \\
$83-500$ & $10-116$ & Soybean cv. Amsoy 71 & Mullen and Koller (1988), Figs 5 and 7 \\
$93-208$ & $12-40$ & Soybean cv. Wells II & Mullen and Koller (1988), Figs 5, 7 \\
90 & $12-35$ & Cucumber & Verkleij and Baan Hofman-Eijer (1988), Fig. 2 \\
$23-46$ & $3-17$ & Cucumber & Verkleij and Challa (1988), Fig. 1, Table 1 \\
\hline $126-224$ & $12-55$ & & Average literature data \\
\hline $45-201$ & $11-32$ & Potato & Present experiments, Table 4 \\
$131-365$ & $13-39$ & Bean & Present experiments, Table 4 \\
\hline
\end{tabular}


1192 Bouma et al.

\section{Calculations of the contribution of the energy costs of carbohydrate export to $\alpha$ : upper limits}

The correlation between the dark respiration rate and the nitrogen concentration of (mature) leaves was hypothesized to be due to energy costs for (1) export of carbohydrates and (2) protein turnover (Lambers et al., 1989). Assuming an average degradation constant of $1.39 \times 10^{-6} \mathrm{~s}^{-1}$, De Visser et al. (1992) showed that protein turnover often accounts for a major part of the effect of the leaf organic nitrogen concentration on the dark respiration $(\alpha)$. If the costs of protein turnover are lower, for example, due to lower degradation constants, the energy costs associated with carbohydrate export may easily account for the remaining part of $\alpha$ (upper limits $a_{\mathrm{e}}$ in Table 3 ). This is especially the case in 21-24-d-old leaves ( $a_{\mathrm{e}}$ up to 1 ). For 17-20-d-old leaves $a_{\mathrm{e}}$ was approximately $50 \%$ lower, due to the higher value of $a: 8.8 \mathrm{nmol}$ $\mathrm{O}_{2}[\mathrm{~g} \mathrm{dw}]^{-1}$ compared to 5.3 for 21-24-d-old leaves (Table 3). We can not account for this high value of $a$, but note that it is also high compared to most observations in (full-grown) leaves of other starch-storing species (up to $7.3 \mathrm{nmol} \mathrm{CO}_{2}$ or $\mathrm{O}_{2}[\mathrm{mmol} \text { organic } \mathrm{N}]^{-1} \mathrm{~s}^{-1} ; \mathrm{De}$ Visser et al., 1992, and references therein; Irving and Silsbury, 1988; Makino and Os'mond, 1991; Pons et al., 1989); only the value obtained by Irving and Silsbury (1987) is as high as that for the 17-20-d-old bean leaves.

\section{Calculations on the contribution of the energy costs of carbohydrate export to $\mathrm{R}_{d}$ : upper and lower limits}

The present export rates $\left(C_{\mathrm{e}}\right)$ and respiratory costs involved in export $\left(R_{\mathrm{e}}\right)$ agree with literature data, although the present export rates are in the lower part of the range (Table 6). Combining the present estimates of the specific costs for carbohydrate export $\left(E_{\mathrm{e}}=0.4-1.2 \mathrm{~mol} \mathrm{CO}_{2}[\mathrm{~mol}\right.$ sucrose $]^{-1}$ ) with literature data (cf. eq. 5), shows that, on average, carbohydrate export explains $12-55 \%$ of leaf dark respiration $\left(R_{\mathrm{e}}\right.$ in Table 6). Some of these high values in the literature, might be partly due to carbohydrate use for leaf growth, which is a relatively expensive process (Poorter et al., 1991). In conclusion, carbohydrate export is an important energy-requiring process in leaves of starch-storing species, at least in the dark. Together with the costs of protein turnover (17-35\% of the leaves' dark respiration as calculated by Bouma et al. [1994]; the range of $5-76 \%$ of leaf dark respiration (De Visser et al. [1992] may include some costs for export), it may account for the major part of dark respiration in full-grown leaves.

\section{Are there energy costs of other processes contributing to $\alpha$ and $R_{d}$ ?}

The sum of the average range of costs associated with carbohydrate $\left(12-55 \%\right.$ of $R_{\mathrm{d}}$; Table 6$)$ plus protein turnover (17-35\% of $R_{\mathrm{d}}$; Bouma et al., 1994) does not exclude the possibility that other energy-dependent processes account for part of the dark respiration of leaves $\left(R_{\mathrm{d}}\right)$. For example, maintaining ion gradients was shown to be important in roots (Bouma and De Visser, 1993). There is also no conclusive evidence to exclude processes other than carbohydrate export and protein turnover, which may contribute to the effect of leaf organic nitrogen concentration on dark respiration $(a)$. One of these processes may be nitrate reduction. For a plant with a relative growth rate of $0.25 \mathrm{~g} \mathrm{~g}^{-1} \mathrm{~d}^{-1}$ and an organic nitrogen concentration of $60 \mathrm{mg} \mathrm{N}(\mathrm{g} \mathrm{dw})^{-1}$, a reduction rate of $12.4 \mathrm{nmol} \mathrm{NO}_{3}^{-}(\mathrm{g} \mathrm{dw})^{-1} \mathrm{~s}^{-1}$ is required to produce the new biomass. The relative importance of nitrate reduction in the shoot increases with increasing nitrate supply (Gojon et al., 1994). Assuming that leaves reduce only the nitrate for their own demand, and using a specific leaf area as observed for potato $\left(47 \mathrm{~m}^{2}[\mathrm{~kg} \mathrm{dw}]^{-1}\right.$; Bouma et al., 1992), the reduction rate is $264 \mathrm{nmol} \mathrm{NO} \mathrm{N} \mathrm{m}^{-2} \mathrm{~s}^{-1}$. Since the reduction of $\mathrm{NO}_{3}^{-}$to $\mathrm{NH}_{3}$ gives $2 \mathrm{~mol} \mathrm{CO}$ $\left[\mathrm{mol} \mathrm{NO}{ }_{3}^{-} \text {reduced }\right]^{-1}$, the calculated nitrate reduction rate gives a $\mathrm{CO}_{2}$ production rate of $528 \mathrm{nmol} \mathrm{CO}_{2}$ $\mathrm{m}^{-2} \mathrm{~s}^{-1}$. In general, and in the present experiments, its contribution is expected to be much lower than calculated here, for the following reasons: (1) nitrate reduction in the leaves occurs predominantly in the light (Beevers and Hageman, 1969; Rufty et al., 1984), (2) up to $1 \mathrm{CO}_{2}$ per nitrate reduced in the shoot may be exported to the root via the malate shuttle (Ben Zioni et al., 1970, 1971; Kirkby and Knight, 1977) and (3) nitrate reduction rate in full-grown leaves is much lower than in growing leaves (Beevers and Hageman, 1969). Moreover, the relative growth rate and organic nitrogen concentration assumed in present calculations were relatively high compared to that of potato (Bouma et al., 1992), so that an upper limit was obtained.

\section{Conclusions}

Dark respiration of full-grown leaves correlates with the nitrogen concentration of these leaves. In starch-storing species, nocturnal carbohydrate export may account for a significant part (up to 100\%) of the slope of this regression, and on average for $29 \%$ of total dark respiration. Thus, in starch-storing species, energy costs associated with nocturnal carbohydrate export are quantitatively important.

\section{Acknowledgements}

The skilful contributions of the members of the analytical laboratory as well as the discussion, critical reading and helpful suggestions of L. Ho, L.F.M. Marcelis, W.J.M. Meijer, R. Rabbinge, and A. Van der Werf are gratefully acknowledged. We would also like to thank R.I. Grange for presenting us unpublished data on the respiration of pepper. 


\section{References}

AOAC. 1984. Williams S, ed. Official methods of analysis of the Association of Official Analytical Chemists. Richmond, Virginia: The William Byrd Press, Inc.

Beck E. 1985. The degradation of transitory starch granules in chloroplasts. In: Heath RL, Preiss J, eds. Regulation of carbon partitioning in photosynthetic tissue. Proceedings of the eighth annual symposium in plant physiology (January $11-12,1985$ ) University of California, Riverside. Baltimore: Waverly Press, 27-44.

Beevers L, Hageman RH. 1969. Nitrate reduction in higher plants. Annual Review of Plant Physiology 20, 495-522.

Ben Zioni A, Vaadia Y, Lips SH. 1970. Correlations between nitrate reduction, protein synthesis and malate accumulation. Physiologia Plantarum 23, 1039-47.

Ben Zioni A, Vaadia Y, Lips SH. 1971. Nitrate uptake by roots as regulated by nitrate reduction products of the shoot. Physiologia Plantarum 24, 288-90.

Bouma TJ, Spitters CJT, De Visser R. 1992. Variation in respiration rate between potato cultivars: effect of developmental stage. In: Lambers $\mathrm{H}$, Van der Plas LHW, eds. Molecular, biochemical and physiological aspects of plant respiration. The Hague: SPB Academic Publishing, 515-22.

Bouma TJ, De Visser R. 1993. Energy requirements for maintenance of ion concentrations in roots. Physiologia Plantarum 89, 133-42.

Bouma TJ, De Visser R, Janssen JHJÄ, De Kock MJ, Van Leeuwen PH, Lambers H. 1994. Respiratory energy requirements and rate of protein turnover in vivo determined by the use of an inhibitor of protein synthesis and a probe to assess its effect. Physiologia Plantarum 92, 585-94.

Caspar T, Huber ST, Somerville C. 1985. Alterations in growth, photosynthesis, and respiration in a starchless mutant of Arabidopsis thaliana (L.) deficient in chloroplast phosphoglucomutase activity. Plant Physiology 79, 11-17.

De Visser R, Spitters CJT, Bouma TJ. 1992. Energy costs of protein turnover: theoretical calculation and experimental estimation from regression of respiration on protein concentration of full-grown leaves. In: Lambers H, Van der Plas LHW, eds. Molecular, biochemical and physiological aspects of plant respiration. The Hague: SPB Academic Publishing, 493-508.

Evans JR. 1983. Nitrogen and photosynthesis in the flag leaf of wheat (Triticum aestivum L.). Plant Physiology 72, 297-302.

Evans JR. 1989. Photosynthesis and nitrogen relationships in leaves of $\mathrm{C}_{3}$ plants. Oecologia 78, 9-19.

Fondy BR, Geiger DR. 1982. Diurnal pattern of translocation and carbohydrate metabolism in source leaves of Beta vulgaris L. Plant Physiology 70, 671-6.

Gardner DCJ, Peel AJ. 1972. Some observations on the role of ATP in sieve tube translocation. Planta 107, 217-26.

Geiger DR. 1975. Phloem loading. In: Zimmermann $\mathrm{MH}$, Milburn JA, eds. Encyclopedia of plant physiology, New Series, Vol. 1: Transport in plants I, Phloem transport. Berlin: Springer-Verlag, 395-431.

Gojon A, Plassard C, Bussi C. 1994. Root/shoot distribution of $\mathrm{NO}_{3}^{-}$assimilation in herbaceous and woody species. In: Roy J, Garnier E, eds. A whole plant perspective on carbonnitrogen interactions. The Hague: SPB Academic Publishing, 131-48.

Grange RI. 1985. Carbon partitioning in mature leaves of pepper: effects of daylength. Journal of Experimental Botany 36, 1749-59.

Grange RI. 1987. Carbon partitioning in mature leaves of pepper: effects of transfer to high or low irradiance. Journal of Experimental Botany 36, 77-83.

Hendrix DL, Grange RI. 1991. Carbon partitioning and export from mature cotton leaves. Plant Physiology 95, 228-33.

Hendrix DL, Huber SC. 1986. Diurnal fluctuations in cotton leaf carbon export, carbohydrate content and sucrose synthesizing enzymes. Plant Physiology 81, 584-6.

Hitz WD. 1982. The contribution of protein turnover and translocation to the respiratory energy demand in darkened, mature barley leaves. Plant Physiology (Supplement) 69, 23.

Ho LC, Thornley JHM. 1978. Energy requirements for assimilate translocation from mature tomato leaves. Annals of Botany 42, 481-3.

Hoagland DR, Snyder WC. 1933. Nutrition of strawberry plants under controlled conditions. Proceedings of the American Society of Horticultural Science 30, 288-94.

Ingestad T. 1979. Nitrogen stress in birch seedlings. II. N, K, $\mathrm{P}, \mathrm{Ca}$, and $\mathrm{Mg}$ nutrition. Physiologia Plantarum 45, 149-57.

Irving DE, Silsbury JH. 1987. A comparison of the rate of maintenance respiration in some crop legumes and tobacco determined by three methods. Annals of Botany 59, 257-64.

Irving DE, Silsbury JH. 1988. The respiration of mature field bean (Vicia faba L.) leaves during prolonged darkness. Annals of Botany 62, 473-9.

Kalt-Torres W, Kerr PS, Usuda H, Huber SC. 1987. Diurnal changes in maize leaf photosynthesis. Plant Physiology 83, 283-8.

Kirkby EA, Knight AH. 1977. Influence of the level of nitrate nutrition on ion uptake and assimilation, organic acid accumulation, and cation-anion balance in whole tomato plants. Plant Physiology 60, 349-53.

Lambers H, Day DD, Azcón-Bieto J. 1983. Cyanide-resistant respiration in roots and leaves. Measurements with intact tissues and isolated mitochondria. Physiologia Plantarum 58, $148-54$.

Lambers H, Freijsen N, Poorter H, Hirose T, Van der Werf A. 1989. Analyses of growth based on net assimilation rate and nitrogen productivity. Their physiological background. In: Lambers $\mathrm{H}$, Cambridge $\mathrm{ML}$, Konings $\mathrm{H}$, Pons $\mathrm{TL}$, eds. Causes and consequences of variation in growth rate and productivity of higher plants. The Hague: SPB Academic Publishing, 1-17.

Lewis JC, Powers EE. 1941. Antagonistic action of chlorides on the toxity of iodides to corn. Plant Physiology 16, 393-8.

Louwerse W, Van Oorschot JLP. 1969. An assembly for routine measurements of photosynthesis, respiration and transpiration of intact plants under controlled conditioning. Photosynthetica 3, 303-15.

Makino A, Osmond B. 1991. Effects of nitrogen partitioning between chloroplasts and mitochondria in pea and wheat. Plant Physiology 96, 355-62.

Mullen JA, Koller HR. 1988. Daytime and night-time carbon balance and assimilate export in soybean leaves at different photon flux densities. Plant Physiology 86, 880-4.

Nátr L. 1975. Influence of mineral nutrition on photosynthesis and the use of assimilates. In: Cooper JP, ed. Photosynthesis and productivity in different environments. Cambridge University Press, 537-55.

Payne RW (ed.). 1987. GENSTAT 5 reference manual. Oxford: Clarendon Press.

Plaut Z, Mayoral ML, Reinhold L. 1987. Effect of altered sink : source ratio on photosynthetic metabolism of source leaves. Plant Physiology 85, 786-91.

Pons TL, Schieving F, Hirose T, Werger MJA. 1989. Optimization of leaf nitrogen allocation for canopy photosyn- 


\section{Bouma et al.}

thesis in Lysimachia vulgaris. In: Lambers $\mathrm{H}$, Cambridge ML, Konings $\mathrm{H}$, Pons TL, eds. Causes and consequences of variation in growth rate and productivity of higher plants. The Hague: SPB Academic Publishing, 175-86.

Poorter H, Van der Werf A, Atkin OK, Lambers H. 1991. Respiratory energy requirements of roots vary with the potential growth rate of plants. Physiologia Plantarum 83, 469-75.

Rufty Jr TW, Israel D, Volk RJ. 1984. Assimilation of ${ }^{15} \mathrm{NO}_{3}^{-}$ taken up by plants in the light and in the dark. Plant Physiology 76, 768-75.

Servaites JC, Geiger DR, Tucci MA, Fondy BR. 1989. Leaf carbon metabolism and metabolite levels during a period of sinusoidal light. Plant Physiology 89, 403-8.

Slone JH, Buckhout TJ. 1991. Sucrose-dependent $\mathrm{H}^{+}$transport in plasma membrane vesicles isolated from sugarbeet leaves (Beta vulgaris L.). Planta 183, 584-9.

Stitt M. 1990. The flux of carbon between the chloroplast and cytoplasm. In: Dennis DT, Turpin DH, eds. Plant physiology, biochemistry and molecular biology. Singapore: Longman Scientific, Technical, 309-26.
Van Bel AJE. 1992. Ecophysiology of phloem loading in source leaves. Plant Cell and Environment 15, 265-70.

Van Bel AJE. 1993. Strategies of phloem loading. Annual Review of Plant Physiology and Plant Molecular Biology 44, 253-81.

Van der Werf A, Poorter H, Lambers H. 1994. Respiration as dependent on a species' inherent growth rate and on the nitrogen supply of the plant. In: Roy J, Garnier E, eds. $A$ whole plant perspective on carbon-nitrogen interactions. The Hague: SPB Academic Publishing, 91-110.

Verkleij FN, Baan Hofman-Eijer L. 1988. Diurnal export of carbon and fruit growth in cucumber. Journal of Plant Physiology 133, 345-8.

Verkleij FN, Challa H. 1988. Diurnal export and carbon economy in an expanding source leaf of cucumber at contrasting source and sink temperature. Physiologia Plantarum 74, 284-93.

Yemm EW. 1965. The respiration of plants and their organs. In: Steward FC, ed. Plant Physiology, Vol. IVA: Metabolism: organic nutrition and nitrogen metabolism. New York and London: Academic Press, 231-310. 